15. Колосов А.М., Лавров Н.П., Михеев А.В. Биология промыслово-охотничьих птиц СССР. М.: Высшая школа, 1983. $311 \mathrm{c.}$

16. Птушенко Е.С., Иноземцев А.А. Биология и хозяйственное значение птиц Московской области и сопредельных территорий. М.: МГУ, 1968. 464 с.

17. Маматов А.Ф. Озерные чайки (Larus ridibun$d u s)$ в Башкирии // Современная орнитология. М.: Наука, 1990. С. 74-85.

18. Климова И.Г., Бушмакин А.Н., Гладкин Н.В., Сухоруков С.Н. Темп откладки яиц и эмбрионального развития озерной чайки на Юго-Востоке Пермской области // Гнездовая жизнь птиц. Пермь,1984. C. 13-19.

19. Rahn Ar.A. The avian egg: incubacion time and water loss. Condor. 1974. № 76. P. 147-150.

20. Отрыганьева А., Позднякова Н., Ромадина Е., Кабакова М. Некоторые вопросы инкубации при загрузке инкубаторов партией одновозрастных яиц // Птицеводство. 1979. № 1. С. 32-34.
21. Романов А.А., Романова А.И. Птичье яйцо. М.: Пищепромиздат, 1959. 620 с.

22. Коляков Я.Е. Ветеринарная иммунология. М.: Агропромиздат, 1986. 272 с.

23. Митюшникова В., Кравинко Н. Контроль уровня естественной резистентности кур // Птицеводство. 1980. № 11. С. 36-38.

24. Крыканов А. Лизоцим белка яиц в оценке воспроизводительных качеств кур // Птицеводство. 1982. № 6. С. 24-25.

25. Познанин Л.П. Эколого-морфологический анализ онтогенеза птенцовых птиц. М.: Наука, 1979. $295 \mathrm{c}$.

26. Шмальгаузен И.И. Проблемы дарвинизма. Л.: Наука, 1969. 493 с.

27. Болотников А.М. Эмбрионизация онтогенеза птиц // Проблемы региональной экологии животных в цикле зоологических дисциплин педвуза. Витебск. 1984. Ч. 1. С. 43-45.

\title{
DURATION OF COLONIAL BIRD SPECIES EGG INCUBATION
}

(C) 2018

Lamekhov Yuri Gennadievich, doctor of biological sciences, professor of General Biology and Physiology Department

South Ural State Humanitarian Pedagogical University (Chelyabinsk, Russian Federation)

Abstract. The paper deals with one of the aspects of bird early ontogenesis biology - egg incubation duration, which was defined as the time interval between egg laying and hatching from it. The oomorphological parameters are determined taking into account the ordinal number of the laid eggs. Parameters of early ontogeny of birds are studied on the example of colonially nesting species: blackberry toadstool (Podiceps nigricollis C.L. Brehm.) and lake gull (Larus ridibundus L.). Within the colonial settlement of these species, the biological center and the periphery of the colony were isolated. When studying the parameters of early ontogeny of birds and oomorphological characteristics, the same number of eggs was taken into account. During field and laboratory studies it was found that the incubation of eggs lasts longer in eggs from the nests of the biological center of the colony. The first eggs are incubated longer. These features clearly manifested in the early ontogeny of the gull. The increase in the egg incubation duration occurs against the background of an increase in their mass and a decrease in the concentration of lysozyme in the protein shell of the egg. Egg incubation duration is one of the results of embryonalization as a way of evolution of ontogeny. The manifestation of the results of embryogenesis was revealed for the first eggs in the nests of the biological center of the colony. Embryonalization leads to an increase in egg incubation duration as well as to a decrease in the intensity of elimination in early ontogenesis, which affects the number of individuals breeding in the colony and, accordingly, the structure of the colonial settlement of birds.

Keywords: bird colony; bird colony structure; colony's biological center; colony periphery; early ontogeny of birds; black-eared toadstool; gull; incubation time; incubation; incubation factors; oviposition; actual incubation; egg serial number; tray nests; egg mass; lysozyme; albuminous membrane of egg; embryogenesis of ontogenesis; evolution of ontogeny.

\section{ЭКОЛОГО-ЦЕНОТИЧЕСКАЯ ПРИУРОЧЕННОСТЬ И РЕСУРСНАЯ ХАРАКТЕРИСТИКА ARCTOSTAPHYLOS UVA-URSI (L.) SPRENG. В КИРОВСКОЙ ОБЛАСТИ}

(C) 2018

Лугинина Екатерина Андреевна, научный сотрудник отдела экологии и ресурсоведения; ассистент кафедры экологии и зоологии

Егошина Татьяна Леонидовна, доктор биологических наук, профессор,

главный научный сотрудник отдела экологии и ресурсоведения; профессор кафедры экологии и зоологии

Всероссийский научно-исследовательский институт охотничьего хозяйства и звероводства им. профессора Б.М. Житкова (г. Киров, Российская Федераичия);

Вятская государственная сельскохозяйственная академия (2. Киров, Российская Федерация)

Аннотация. В работе представлены материалы по фитоценотической приуроченности и ресурсным параметрам Arctostaphylos uva-ursi в Кировской области. В сосняке травяно-лишайниковом подзоны хвойношироколиственных лесов вид наиболее близок к фитоценотическому оптимуму, где ценопопуляции толокнянки обыкновенной наиболее урожайны $(56,1 \pm 4,2$ г/м²) и вид имеет наибольшее проективное покрытие 
$(16,8 \pm 1,1 \%)$, и длину побегов $(17,7 \pm 0,8$ см). Показатели участия A. uva-ursi в сложении сообществ увеличиваются при продвижении с севера на юг области. A. uva-ursi приурочена к песчаным и супесчаным сильнокислым (рН 3,4-4,0), бедным гумусом с незначительным содержанием фосфора, калия, кальция и магния почвам. Выявлена достоверная (р <0,05) зависимость между величиной урожайности листьев A. uva-ursi и содержанием магния $(\mathrm{r}=0,85)$ в почве. Установлен прямолинейный и достоверный характер связи между проективным покрытием, численностью побегов и урожайностью $\left(\mathrm{R}^{2}=0,71-0,97\right)$. Величина урожайности сырья может быть представлена уравнением регрессии, имеющим следующий общий вид:

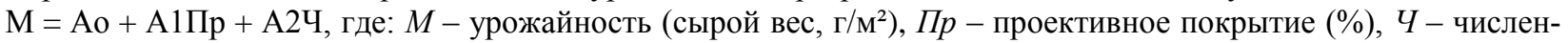
ность побегов (шт./M²).

Биологический запас (Бз) толокнянки в Кировской области составляет 285,5 т. Распределение его по растительным подзонам и административным районам неравномерное: 51\% биологического запаса (144,7 т) сосредоточено в подзоне средней тайги. Эксплуатационный запас толокнянки в области составляет 109,1 т. Объем возможные ежегодные заготовки - 7,9 т. Он достаточен для заготовок сырья для местных нужд.

В условиях Кировской области в сосняках лишайниковых с пятнами толокнянки полного восстановления зарослей при срезании 75\% периферических побегов не происходит даже при заготовке сырья 1 раз в 5 лет.

Ключевые слова: Arctostaphylos uva-ursi; фитоценотическая приуроченность; фитоценотический оптимум; ценоареал; урожайность; проективное покрытие; биологический запас; эксплуатационный запас; объем возможных ежегодных заготовок; эксплуатационный пресс; восстановление; Кировская область.

\section{Введение}

Рациональное использование запасов растительных ресурсов невозможно без выявления фитоценотической приуроченности вида и его ресурсной характеристики, включающей сведения о продуктивности вида в различных сообществах и экологических условиях.

Знание ценокомплекса вида и параметров экологических факторов, при которых каждый вид ресурсных растений достигает максимальной для него урожайности, позволяет прогнозировать местонахождение высокоурожайных и устойчивых популяций [1].

В Кировской области и в стране в целом достаточно хорошо изучены ресурсные характеристики хозяйственно-важных видов сем. Ericaceae [2-13].

\section{объект и методика исследований}

Толокнянка обыкновенная (Arctostaphylos uvaursi (L.) Spreng) (сем. Ericaceae) является значительно менее исследованным видом. В литературе имеются сведения о ресурсных параметрах вида в Сибири, прежде всего в Центральной Якутии [14]. Данные о ресурсных параметрах и фитоценотической приуроченности вида в европейской части страны фрагментарны [15-17]. Поэтому изучение эколого-ценотической приуроченности и выявление ресурсной характеристики A. uva-ursi в Кировской области является актуальной задачей.

А. uva-ursi - длиннокорневищный вечнозеленый кустарничек, хамефит [18, с. 150], образует куртины, в которых ортопропные побеги расположены в центре, плагиотропные - по периферии. Используется в официальной (Государственная фармакопея..., ХІ (далее - ГФ ХІ) [19] и народной [20] медицине, является кормовым [21, с. 205] и декоративным растением. Вероятно, A. uva-ursi, как и многие таежные представители сем. Ericaceae, являются магниофилами и накопителями магния, что отмечено в литературных источниках ([22; 23, с. $16,30,218 ; 24])$. Сoдержание арбутина в листьях толокнянки обыкновенной в регионе исследования, как показано Н.Ю. Чирковой [25], соответствует требованиям ГФ XI [19], достигая максимального значения на открытых участках.

Территория Кировской области входит в ценоареал вида. В южнее расположенных сопредель- ных регионах, например в Республике Татарстан, толокнянка обыкновенная - редкий вид, нуждающийся в охране, категория 2 [26, с. 369-370], который встречается лишь в северной части республики.

При изучении популяций А. uva-ursi применялись методы постоянных пробных площадей и ключевых участков с последующей экстраполяцией данных на однотипные фитоценозы [27].

В отобранных из корнеобитаемого слоя почвенных пробах определялись основные агрохимические показатели: кислотность ( $\mathrm{pH})$, содержание гумуса, фосфора, калия, кальция, магния [28], дающие возможность выявить взаимосвязи между свойствами почвы и продуктивностью растений.

Опыты по влиянию эксплуатационного стресса на состояние популяций A. uva-ursi были заложены, согласно рекомендациям И.Л. Крыловой [29], в сосняке лишайниковом с пятнами толокнянки среднетаежной подзоны (Нагорского района Кировской области). A. uva-ursi встречается здесь куртинами размером от $4 \mathrm{~m}^{2}$ до $50 \mathrm{M}^{2}$, занимая около $10 \%$ от общей площади массива, составляющего 212 га [30].

Почва участка - среднеоподзоленная, песчаная со следующими агрохимическими показателями корнеобитаемого слоя - $\mathrm{pH} 4,0$, содержание фосфора - 3,0 г/100 г почвы, калия - 1,4 г/100 г почвы, кальция 0,50 мг-экв/100 г почвы, магния - 0,18 мг-экв/100 г почвы, гумуса - 0,50\%. Состав древостоя - $10 \mathrm{C}$. Средний возраст насаждения - 20 лет, средняя высота древостоя - 3 м. Сомкнутость крон древостоя 0,3. Подрост составлен единичными соснами, осинами. Подлесок как ярус не развит, встречаются отдельные экземпляры Cytisus ruthenicus. Фитоценотическая роль его весьма незначительна.

Травяно-кустарничковый ярус разреженный, проективное покрытие его $15 \%$. Доминирует в нем A. uva-ursi, имеющая проективное покрытие около 10\%. Рассеянно встречаются Antennaria dioica, Diphasiastrum complanatum, Calamagrostis arundinacea, Hieracium umbellatum, Pilosella officinarum, единичны Gnaphalium sylvaticum, Chaemaenerion angustifolium. Лишайниковый покров занимает 70\% площади участка, представлен Cladonia sylvatica (62\%), C. rangiferina $(10 \%)$.

В ходе эксперимента срезалось 75\% периферических побегов. Такой процент изъятия определен 
предварительно при наблюдениях за работой реальных заготовительных бригад, где было выявлено, что при заготовках срезается 71,2 $\pm 5,1 \%$ периферических побегов куртины. Центр куртин сборщики не используют, т.к. на побегах в центре куртин много почерневших листьев и безлистных побегов. На участке было заложено 6 трансект, на каждой из которых в пределах периферических частей куртин толокнянки располагалось 25 учетных площадок одного из вариантов опыта: вариант 1 - срезка побегов ежегодно, вариант 2 - срезка побегов через 1 год, вариант 3 - срезка побегов через 2 года, вариант 4 срезка побегов через 3 года, вариант 5 - срезка побегов через 4 года, вариант 6 - срезка побегов через 5 лет.

\section{Результаты исследования и их обсуждение}

В Кировской области A. uva-ursi произрастает в редкостойных сосняках лишайниковых и брусничных с полнотой насаждения 0,3-0,4, расположенных на боровых террасах рек.

В сосняках лишайниковых с пятнами A. uva-ursi преобладают лишайники из p. Cladonia. Обедненный травяно-кустарничковый ярус представлен Lycopodium complanatum, Antennaria dioica, Hieracium pilosella, Gnaphalium sylvaticum, Calamagrostis epigeios. В подзоне хвойно-широколиственных лесов в таких ассоциациях также единично встречаются Solidago virgaurea, Polygonatum officinale, Pulsatilla patens, Rubus saxatilis, Viola montana, Silene nutans. В сосняках травяно-лишайниковых с пятнами A. uva-ursi отмечены эти же виды растений, но степень участия их в сложении сообщества несколько выше. В травянокустарничковом ярусе сосняков брусничных $A$. uvaursi является содоминантом наряду с Vaccinium vitisidaea, часто брусника имеет более высокое проективное покрытие. Значительно участие в сложении травяно-кустарничкового яруса Vaccinium myrtillus, обычны также Luzula pilosa, Lycopodium complanatum, Milium effusum, Calamagrostis epigeios. Всего в травяно-кустарничковом ярусе сообществ с A. uvaursi выявлено свыше 20 видов сосудистых растений.

A. uva-ursi приурочена к песчаным и супесчаным сильнокислым (рН 3,4-4,0), бедным гумусом $(0,28-$ $1,70 \%)$, с незначительным содержанием фосфора (1,6-15,5 мг/100 г почвы), калия (1,2-3,8 мг/100 г почвы), кальция (0,37-1,53 мг/100 г почвы) и магния (0,16-2,0 мг/100 г почвы) почвам. Эдафическая приуроченность вида в регионе исследований уже диапазонов варьирования значений отдельных агрохимических параметров. Так, согласно исследованиям Т.А. Полянской и Л.А. Жуковой [31], толокнянка обыкновенная мезовалентна по шкалам богатства почв и эвривалента по шкалам кислотности почв.

Отмечено, что в подзоне хвойно-широколиственных лесов A. uva-ursi встречается на более богатых гумусом и минеральными веществами почвах, чем в подзоне средней тайги.

В вышеуказанных типах леса A. uva-ursi встречается небольшими пятнами (3-50 $\left.\mathrm{m}^{2}\right)$. Наиболее урожайны ценопопуляции толокнянки обыкновенной в сосняках травяно-лишайниковых $(56,1 \pm 4,2$ г/м²), в этих же сообществах толокнянка имеет наибольшее проективное покрытие $(16,8 \pm 1,1 \%)$ и длину побегов $(17,7 \pm 0,8$ см) (табл. 1$)$.

Наименее урожайны ценопопуляции в сосняках

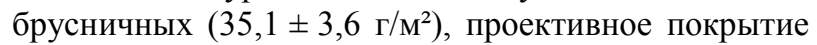
растений $A$. uva-ursi в этих ассоциациях также минимально $(10,7 \pm 0,9 \%)$.

Показатели участия A. uva-ursi в сложении сообществ изменяются при продвижении с севера на юг области. Среднее проективное покрытие увеличивается от $10,1 \pm 1,2 \%$ в подзоне средней тайги до $19 \pm 2,0 \%$ в подзоне хвойно-широколиственных лесов.

Таблица 1 - Характеристика ценопопуляций Arctostaphylos uva-ursi (L.) Spreng. в различных типах лесных фитоценозов

\begin{tabular}{|l|c|c|c|c|}
\hline \multicolumn{1}{|c|}{ Тип фитоценоза } & $\begin{array}{c}\text { Количество обследованных } \\
\text { ценопопуляций }\end{array}$ & $\begin{array}{c}\text { Проективное } \\
\text { покрытие, } \%\end{array}$ & $\begin{array}{c}\text { Длина } \\
\text { побегов, см }\end{array}$ & $\begin{array}{c}\text { Урожайность, Г/м² } \\
\text { (сырая масса) }\end{array}$ \\
\hline Сосняк лишайниковый & 42 & $14,0 \pm 1,5$ & $11,6 \pm 0,5$ & $104,6 \pm 7,8$ \\
\hline $\begin{array}{l}\text { Сосняк травяно- } \\
\text { лишайниковый }\end{array}$ & 28 & $16,8 \pm 1,1$ & $17,7 \pm 0,8$ & $112,2 \pm 7,2$ \\
\hline Сосняк брусничный & 26 & $10,7 \pm 0,9$ & $14,1 \pm 0,6$ & $70,2 \pm 5,2$ \\
\hline
\end{tabular}

Наибольшая урожайность A. иva-ursi отмечена в сосняке травяно-лишайниковом в подзоне хвойношироколиственных лесов, где она достигла $138,0 \pm 8,16 \Gamma / \mathrm{M}^{2}$, что почти в 4 раза выше, чем в среднем в данном типе фитоценозов в подзоне средней тайги. Вероятно, условия произрастания толокнянки обыкновенной в сосняке травяно-лишайниковом подзоны хвойно-широколиственных лесов наиболее близки к фитоценотическому оптимуму, согласно рекомендации И.Л. Крыловой (1985), предложившей считать величину надземной фитомассы критерием близости к фитоценотическому оптимуму.

Полученные значения урожайности A. uva-ursi близки к величинам урожайности данного вида для некоторых европейских регионов России, Белоруссии и Литвы (от 5,8 до 176,0 г/м²) [15; 32-36], но значительно ниже таковых, приводимых для централь- ной Якутии, юга Иркутской области, зоны БАМ (от

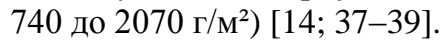

Выявлена достоверная $(\mathrm{p}<0,05)$ зависимость между величиной урожайности листьев A. uva-ursi и содержанием магния $(\mathrm{r}=0,85)$ в почве.

Все показатели участия А. uva-ursi в сложении фитоценозов (проективное покрытие, высота побегов, урожайность) взаимосвязаны с величиной сомкнутости крон древостоя $(\mathrm{r}=-0,53 ; \mathrm{r}=-0,52 ; \mathrm{r}=-$ $0,60$ соответственно при $\mathrm{p}<0,05)$. Выявленные отрицательные зависимости подтверждают описанные в литературе факты снижения урожайности и проективного покрытия A. uva-ursi с уменьшением освещенности местообитаний [15; 31].

Методом множественного регрессионного анализа выявлена достоверная зависимость $(\mathrm{R}=0,71-0,97)$ между урожайностью сырья и проективным покры- 
тием надземной части лекарственных растений. В общем виде величина урожайности сырья может быть представлена уравнением регрессии, имеющим следующий общий вид:

$$
\mathrm{M}=\mathrm{Ao}+\mathrm{A} 1 \Pi \mathrm{p}+\mathrm{A} 2 \mathrm{\Psi},
$$

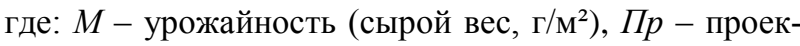
тивное покрытие $(\%), \quad$ - численность побегов (штук $\left./ \mathrm{M}^{2}\right)$.

Верификация на независимом материале (рис. 1) показала возможность использования выявленной зависимости между величинами урожайности, проективного покрытия вида и численности побегов для целей экспресс-определения урожайности листьев толокнянки обыкновенной без отторжения фитомассы.

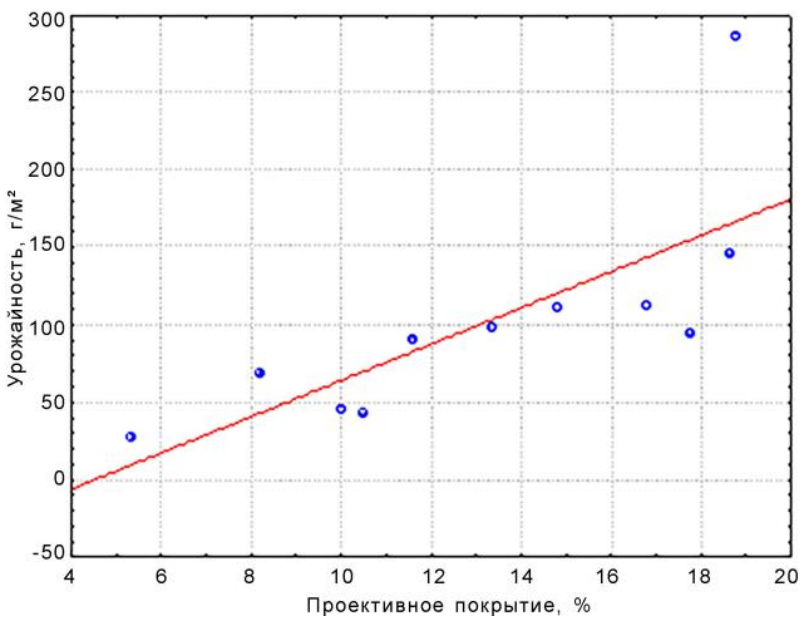

Рисунок 1 - График экспресс-определения урожайности Arctostaphylos uva-ursi (L.) Spreng. (листья, сырая масса)

с верификацией на независимом материале

В условиях отсутствия конкурентов толокнянка обыкновенная, по данным некоторых исследователей (В.Ф. Сотник [16], Т.А. Полянская, Л.А. Жукова [31]), хорошо возобновляется на вырубках. Но сроки восстановления вида под влиянием эксплуатационного пресса не установлены. Ряд авторов, изучавших восстановление вида после эксплуатационного стресса в Литве (Е.П. Шимкунайте [32], Д.К. Будрюнене [36], указывают на необходимость чередования мест заготовок листьев толокнянки, предлагая возвращаться на один и тот же массив через 4-6 лет, срезая не более $75 \%$ побегов куртины. Исследователи, работавшие в Ленинградской (В.Г. Регир [17]), Псковской и Вологодской (В.Ф. Сотник [33]) областях, в Карелии (Т.Г. Воронова [15]), в Сибири (В.Ф. Мухина [40]), указывают на допустимость срезки лишь $30-50 \%$ побегов и повторного возврата на эти участки через 6-10 лет. В.Г. Регир [17] установила, что после однократной заготовки сырья в сосняке бруснично-вересковом урожайность $A$. uva-ursi уменьшилась в 15 раз, а в сосняке беломошнике - в 31 раз по сравнению с контрольными площадками. В.Ф. Сотник [33] указывает, что толокнянка восстанавливается на гарях, где нет конкурентов, в течение 3-5 лет. Т.Г. Воронова [15] установила, что при интенсивной заготовке сырья (срезке 75\% побегов в куртине) на пятый год количество побегов составляет $51 \%$, биомасса - 39\% от первоначальных величин. При срезке
$50 \%$ побегов, по мнению Т.Г. Вороновой [15], полного восстановления заросли A. uva-ursi можно ожидать через 6-8 лет. В.Ф. Мухина [40] и Л.К. Поздняков, В.Ф. Мухина, В.М. Вершняк [14] указывают, что в сосняках толокнянковой группы в Сибири следует заготавливать верхушечные побеги, срезая 30$40 \%$ надземной биомассы в центральной части заросли, что обеспечивает ее возобновление через 710 лет.

Данные, характеризующие состав ненарушенной заросли в 1991 г. и в 1997 г. (контроль), приведены в таблице 2. Показатели участия вида в сложении сообщества в контроле в начале и конце опыта наблюдений не имели достоверных отличий.

Таблица 2 - Характеристика изменений состава популяции Arctostaphylos uva-ursi (L.) Spreng. в начале и конце опыта (контроль)

\begin{tabular}{|l|c|c|c|}
\hline $\begin{array}{c}\text { Год } \\
\text { наблюдения }\end{array}$ & $\begin{array}{c}\text { Высота } \\
\text { побегов, } \\
\text { см }\end{array}$ & $\begin{array}{c}\text { Проектив- } \\
\text { ное покры- } \\
\text { тие, \% }\end{array}$ & $\begin{array}{c}\text { Урожайность, } \\
\text { г/м² } \\
\text { (сырая масса) }\end{array}$ \\
\hline 1991 & $24,7 \pm 1,2$ & $16,8 \pm 1,1$ & $112,2 \pm 7,1$ \\
\hline 1996 & $24,8 \pm 1,7$ & $19,6 \pm 1,9$ & $98,9 \pm 8,7$ \\
\hline $\begin{array}{l}\text { Критерий } \\
\text { Стъюдента }\end{array}$ & 0,56 & 0,50 & 1,52 \\
\hline
\end{tabular}

Ежегодная срезка побегов (вариант 1) привела к сильной регрессии заросли уже после второй срезки побегов. Весной 1993 г. опыт в этом варианте использования A. uva-ursi пришлось прервать, т.к. на всех площадках после второй срезки побегов не произошло сколь-нибудь существенного восстановления заросли. Развилось лишь несколько слабых, мелких побегов из спящих почек.

При срезке побегов через год (вариант 2) в конце опыта биомасса побегов уменьшилась почти в 15 раз и составила лишь 6,8 г/ $\mathbf{M}^{2}$. Аналогичные изменения отмечены для величины проективного покрытия, которая снизилась после первой срезки сырья на 78,6\%, после второй - на 88,8\%. Значительно меньшее снижение отмечено для показателей высоты побегов (на $80,5 \%$ после второй срезки). Все показатели достоверно отличались от контрольных при Р < 0,001.

При срезке побегов через 2 года (вариант 3) все показатели в конце опыта существенно уменьшились и достоверно отличались от контрольных (при $\mathrm{P}<0,001)$. Наиболее значительно уменьшилась величина биомассы. Она составила $23,1 \%$ от исходной. Величина проективного покрытия снизилась на $68,8 \%$, высота побегов - на 37,6\%.

При срезке побегов через 3 года (вариант 4) также отмечено снижение всей изученных показателей по сравнению с контролем. Но оно не столь сильно, как в вариантах 1-3. Величина биомассы составила $29,5 \%$ исходной. Величина проективного покрытия составила $38,1 \%$ от исходной. Высота побегов также уменьшилась и составила 58,7\% исходной. Все показатели достоверно отличались от контроля при $\mathrm{P}<0,001$.

При срезке побегов через 4 года (вариант 5) все изученные показатели также значительно отличались от исходных. Величина проективного покрытия составила 78,3\% от исходной, не отличаясь достоверно от контроля, биомассы - 56,4\%, достоверно отличаясь от контроля при $\mathrm{P}<0,01$, высота побегов - 
$58,7 \%$, достоверно отличались от контроля при $\mathrm{P}<0,001$.

При срезке побегов через 5 лет (вариант 6) все изученные показатели достоверно не отличались от исходных. Величина проективного покрытия составила $103,1 \%$ от исходной, биомассы - 96,7\%, высота побегов - 96,1\%. Все показатели участия вида в сложении сообщества достоверно не отличались от контроля не отличаясь достоверно от при $\mathrm{P}<0,001$.

Проведенный эксперимент позволяет заключить, что в условиях Кировской области в сосняках лишайниковых с пятнами толокнянки полного восстановление зарослей при срезании 75\% периферических побегов происходит даже при заготовке сырья 1 раз в 5 лет. На основании полученных материалов следует рекомендовать в регионе оборот заготовки 6 лет. Данная величина оборота заготовки близка к рекомендациям других исследователей, работавших как в европейской части страны, так и в Сибири (В.Г. Регир [17], В.Ф. Сотник [33], Т.Г. Воронова [15], В.Ф. Мухина [40], по мнению которых восстановление зарослей толокнянки обыкновенной после отторжения 75\% периферических побегов происходит в течение 6-10 лет.

Общая площадь зарослей толокнянки обыкновенной на территории Кировской области составляет 731 га. Значительная часть зарослей размещена в подзоне средней тайги (441 га или 60\%). В подзоне южной тайги сосредоточено лишь $33 \%$ площади (239 га) массивов толокнянки, в подзоне хвойношироколиственных лесов - 7\% (51 га). Наибольшие площади зарослей толокнянки выявлены в Лузском (180 га), Верхнекамском (145 га), Нолинском (60 га), Афанасьевском (40 га), Нагорском (40 га), Кильмезском (36 га) районах.

Биологический запас (Бз) толокнянки в Кировской области составляет 285,5 т. Распределение его по растительным подзонам и административным районам неравномерное: $51 \%$ биологического запаса $(144,7$ т) сосредоточено в подзоне средней тайги, $28 \%(79,7$ т) - в подзоне средней тайги и $21 \%(61,1$ т) - в подзоне хвойно-широколиственных лесов. Степень агрегированности Бз A. uva-ursi в регионе исследования довольно низкая: относительная плотность запаса сырья не превышает 5,2 кг/км².

Эксплуатационный запас толокнянки в области составляет 109,1 т. Его распределение по растительным подзонам и административным районам исследованной территории аналогично таковому биологического запаса.

Объем возможных ежегодных заготовок толокнянки в Кировской области - 7,9 т. Характер его распределения по растительным подзонам аналогичен таковому для величин Бэ и Эз. Наиболее значительные объемы заготовок возможны в Лузском $(1,1 \mathrm{~T})$, Верхнекамском (0,8 т), Нолинском $(1,4 \mathrm{~T})$, Кильмезском $(0,6 \mathrm{~T})$ районах.

Объем возможных ежегодных заготовок сырья A. uva-ursi в выявленных массивах не превышает $1,0 \mathrm{~T}$.

\section{Bыводы}

В Кировской области Arctostaphylos uva-ursi (L.) Spreng. произрастает в редкостойных сосняках лишайниковых и брусничных с полнотой насаждения 0,3-0,4, расположенных на боровых террасах рек.
Условия произрастания толокнянки обыкновенной в сосняке травяно-лишайниковом подзоны хвойно-широколиственных лесов наиболее близки к фитоценотическому оптимуму.

Наиболее урожайны ценопопуляции толокнянки обыкновенной в сосняках травяно-лишайниковых $\left(56,1 \pm 4,2 \Gamma / \mathrm{M}^{2}\right)$, в этих же сообществах толокнянка имеет наибольшее проективное покрытие $(16,8 \pm$ $\pm 1,1 \%)$ и длину побегов $(17,7 \pm 0,8$ см). Выявлен прямолинейный и достоверный характер связи между проективным покрытием, численностью побегов и урожайностью $\left(\mathrm{R}^{2}=0,71-0,97\right)$. Показатели участия A. uva-ursi в сложении сообщества увеличиваются при продвижении с севера на юг области.

A. uva-ursi приурочена к песчаным и супесчаным сильнокислым (pH 3,4-4,0), бедным гумусом $(0,28-$ $1,70 \%)$, с незначительным содержанием фосфора (1,6-15,5 мг/100 г почвы), калия (1,2-3,8 мг/100 г почвы), кальция (0,37-1,53 мг/100 г почвы) и магния (0,16-2,0 мг/100 г почвы) почвам. Выявлена достоверная $(\mathrm{p}<0,05)$ зависимость между величиной урожайности листьев A. uva-ursi и содержанием магния $(\mathrm{r}=0,85)$ в почве.

Биологический запас (Бз) толокнянки обыкновенной в Кировской области составляет 285,5 т. Эксплуатационный запас - 109,1 т - 7,9 т, объем возможных ежегодных заготовок - 1,0 т.

В условиях Кировской области в сосняках лишайниковых с пятнами толокнянки полное восстановление зарослей при отторжении 75\% периферических побегов происходит при заготовке сырья 1 раз в 6 лет.

\section{Список литературы:}

1. Пименова Р.Е. Запасы сырья Cimicifuga daurica (Turcz.) Maxim. в Приморском крае // Растительные ресурсы. 1971. Т. VII, вып. 3. С. 344-352.

2. Юдина В.Ф., Белоногова Т.В., Колупаева К.Г. Брусника. М., 1986. 79 с.

3. Современное состояние недревесных растительных ресурсов России. Киров: ВНИИОЗ, 2003. $263 \mathrm{c}$.

4. Егошина Т.Л. Недревесные растительные ресурсы России. М.: НИА-Природа, 2005. 80 с.

5. Егошина Т.Л., Колупаева К.Г., Рычкова Н.Н. [и др.]. Ресурсы Vaccinium vitis - idaea (Ericaceae) в Кировской области. Сообщение 1. Фитоценотическая приуроченность и запасы // Растительные ресурсы. 2005. Т. 41, вып. 1. С. 72-82.

6. Егошина Т.Л., Колупаева К.Г., Скрябина А.А. [и др.]. Ресурсы Oxycoccus palustris (Ericaceae) в Кировской области // Растительные ресурсы. 2005. Т. 41, вып. 4. С. 50-60.

7. Егошина Т.Л., Колупаева К.Г., Раус Л.К. Анализ особенностей плодоношения и ресурсов Vaccinium myrtillus (Ericaceae) в Кировской области (19612004) // Растит. ресурсы, 2006. Т. 42, вып. 1. С. 57-66.

8. Egoshina T.L., Luginina E.A. Vaccinium vitis-ida$e a$ and Oxycoccus palustris in natural Populations and Culture in Taiga Zone of Russia // Acta horticulturae et regiotecturae, 2007, № 10. P. 57-61.

9. Егошина Т.Л., Лугинина Е.А. Ресурсы брусники (Vaccinium vitis-idaea L.) и клюквы (Oxycoccus palustris Pers.) в природных популяциях таежной зоны России и перспективы культивирования // Вест- 
ник Тверского государственного университета. Серия «Биология и экология». 2008. Вып. 10. С. $147-$ 154.

10. Чиркова Н.Ю. Особенности накопления арбутина в листьях Arctostaphylos uva-ursi (L.) Spreng. в зависимости от освещенности местообитания // Актуальные проблемы регионального экологического мониторинга: научный и образовательный аспекты: сб. материалов всерос. научной школы (г. Киров, 2830 ноября 2006 г.). Киров: Изд-во ВятГГУ, 2006. C. $49-51$.

11. Чиркова Н.Ю., Сулейманова В.Н. Оценка возможностей введения в культуру и перспективы культивирования хозяйственно ценных видов дикорастущих ягодников Кировской области // Вестник Оренбургского государственного университета: Еcтественные науки. 2010. № 5 (111). С. 115-119.

12. Егошина Т.Л. Недревесные растительные ресурсы и их значение для населения России // Пищевые ресурсы дикой природы и экологическая безопасность населения: матер. междунар. конфер. 1618 ноября 2004 г. Киров: ВНИИОЗ, 2004. С. 14-16.

13. Лугинина Е.А. Ресурсы дикорастущих лекарственных, ягодных, плодовых растений и грибов в Кировской области и особенности их использования // Пищевые ресурсы дикой природы и экологическая безопасность населения: материалы международной конф. 16-18 ноября 2004 г. Киров: ВНИИОЗ, 2004. C. $70-71$.

14. Поздняков Л.К., Мухина В.Ф., Вершняк В.М. Толокнянка в лесах Якутии и Средней Сибири. М., 1978. $69 \mathrm{c}$.

15. Воронова Т.Г. Эколого-ценотические особенности брусники и толокнянки // Ресурсы недревесной продукции лесов Карелии. Петрозаводск. 1981. С. 50-74.

16. Сотник В.Ф. Ресурсы толокнянки в Европейской части СССР: автореф. дис. ... канд. биол. наук. Л., 1969.18 с.

17. Регир В.Г. Влияние заготовки сырья на возобновление листьев толокнянки - Arctostaphylos uvaursi (L.) Spreng. // Вопросы фармакогнозии. 1968. Вып. 5. С. 37-39.

18. Ведерникова О.П., Быченко Т.М., Османова Г.О. Лекарственные растения. Разнообразие жизненных форм. Йошкар-Ола: ООО ИПФ «Стринг», 2005.168 c.

19. Государственная фармакопея СССР: Вып. 2. Общие методы анализа. Лекарственной растительное сырье. ХІ изд., доп. М.: Медицина, 1989. 400 с.

20. Егошина Т.Л., Лугинина Е.А., Кириллов Д.В. Лекарственные растения и грибы народной медицины Кировской области: особенности использования и ресурсы // Вестник Оренбургского государственного университета. 2016. № 4 (192). С. 66-71.

21. Ларин И.В., Абагабян Ш.М., Работнов Т.А. [и др.]. Кормовые растения сенокосов и пастбищ СССР. Т. 3. М.-Л., 1956.880 с.

22. Мусаева Л.Д., Козлова Г.И. Содержание марганца в лекарственных растениях (дикорастущих ягодниках) порядка Верескоцветных / Дикорастущие ягодники СССР. Петрозаводск, 1980. С. 119-120.

23. Ловкова М.Я., Рабинович А.М., Пономарева С.М. [и др.]. Почему растения лечат. М.: Наука, 1990. $256 \mathrm{c}$.
24. Егошина Т.Л., Орлов П.П., Шулятьева Н.А. Элементный состав некоторых лекарственных и ягодных растений порядка Верескоцветных // Биоразнообразие и биоресурсы Урала и сопредельных территорий: материалы второй междунар. конф. Оренбург. 2001. С. 97-98.

25. Чиркова Н.Ю. Некоторые особенности развития и продуктивности брусничников на вырубках южно-таежных брусничниково-зеленомошных сосняков // Лесное хозяйство. 2007. № 4. С. 22-23.

26. Красная книга Республики Татарстан. Казань: Изд-во «Идел-Пресс», 2016. 760 с.

27. Мазная Е.А. Оценка запасов растений, имеющих хозяйственное значение // Методы изучения лесных сообществ. 2002. СПб. С. 95-102.

28. Аринушкина Е.В. Руководство по химическому анализу почв. М., 1962. 452 с.

29. Крылова И.Л. Способы определения сроков восстановления запасов сырья лекарственных растений // Растительные ресурсы. 1981. Т. 17, вып. 3. C. $446-450$.

30. Лугинина Е.А., Егошина Т.Л. Влияние эксплуатационного стресса на состояние ценопопуляций толокнянки (Arctostaphylos uva-ursi (L.) Spreng., Ericaceae) // VII Зыряновские чтения: материалы всерос. науч.-практ. конф., Курган, 10-11 декабря 2009. Курган: Изд-во Курганского ун-та, 2009. С. 216-218.

31. Полянская Т.А., Жукова Л.А. Онтогенез толокнянки обыкновенной (Arctostaphylos uva-ursi (L.) Spreng) // Онтогенетический атлас растений. T.VII. Йошкар-Ола: ООО ИПФ «Стринг», 2013. 364 с.

32. Шимкунайте Е.П. Биологические основы использования ресурсов лекарственных растений Литвы: автореф. дис. ... д-ра биол. наук. Вильнюс, 1970. $58 \mathrm{c}$.

33. Сотник В.Ф. Планирование заготовок лекарственных растений с учетом их биологических особенностей (на примере толокнянки) // Ресурсы дикорастущих лекарственных растений СССР. М., 1972. C. $65-66$.

34. Харитонова Н.П., Макарова Л.О. Урожайность толокнянки в некоторых районах Удмуртии // Науч. тр. Перм. фарм. ин-та. 1971. Вып. 4. С. 119-123.

35. Ненадович Ф.И. Эколого-географические особенности произрастания и продуктивность Arctostaphylos uva-ursi (L.) Spreng. в Белоруссии // Ботаника. 1978. Вып. 20. С. 178-183.

36. Будрюнене Д.К. Влияние хозяйственной деятельности в лесах на состояние и продуктивность зарослей толокнянки обыкновенной (Рекомендации производству). Каунас, 1984. 15 с.

37. Горохова Г.И. Продуктивность некоторых лекарственных растений западного участка БАМ // Растит. ресурсы. 1979. Т. XV, вып. 1. С. 62-63.

38. Мухина В.Ф. Оценка плотности запаса Arctostaphylos uva-ursi (L.) Spreng. в Центральной Якутии // Растит. ресурсы. 1995. Т. 31, вып. 2. С. 75-78.

39. Федосеева Г.М., Пешкова В.А., Наркевич В.В. [и др.]. Запасы сырья дикорастущих лекарственных растений в южных районах Иркутской области // Растит. ресурсы. 1997. Т. 33, вып. 1. С. 42-48.

40. Мухина В.Ф. Скорость восстановления надземной фитомассы Arctostaphylos uva-ursi (L.) Spreng. после заготовки сырья // Растительные peсурсы. 1988. Т. 24, вып. 2. С. 199-207. 


\section{ECOLOGICAL-COENOTIC CONFINEMENT AND RESOURCES CHARACTERISTICS OF ARCTOSTAPHYLOS UVA-URSI (L.) SPRENG. IN KIROV REGION}

(C) 2018

Luginina Ecaterina Andreevna, researcher of Ecology and Plant Resources Department; assistant of Ecology and Zoology Department

Egoshina Tatiana Leonidovna, doctor of biological sciences, professor,

chief researcher of Ecology and Plant Resources Department; professor of Ecology and Zoology Department Professor Zhitkov Russian Research Institute of Game Management and Fur Farming (Kirov, Russian Federation); Vyatka State Agricultural Academy (Kirov, Russian Federation)

Abstract. The paper presents data on phytocoenotic confinement and resource parameters of Arctostaphylos uvaursi in Kirov Region. The species is close to phytocoenotic optimum in pine herbaceous-lichen forests in coniferousbroadleaved forests sub zone. The highest productivity of $A$. uva-ursi coenopopulations is marked in pine hebaceouslichen forests $\left(56,1 \pm 4,2 \mathrm{~g} / \mathrm{m}^{2}\right)$ where the species has maximum coverage $(16,8 \pm 1,1 \%)$ and shoot length $(17,7 \pm 0,8$ $\mathrm{cm}$ ). Presence of A. uva-ursi in communities increases southwards within the Region. A. uva-ursi is restricted to sandy and sabulous soils with high acidity level ( $\mathrm{pH} 3,4-4,0)$, humus poor and insignificant content of phosphorus, potassium, calcium and magnesium. Reliable relation $(\mathrm{p}<0,05)$ between A. uva-ursi leaves productivity and $\mathrm{Mg}$ content in soil $(\mathrm{r}=0,85)$ was defined. We have also determined straight and reliable connection between coverage, shoots number and productivity $\left(\mathrm{R}^{2}=0,71-0,97\right)$. Raw material productivity can be presented by regression equation: $\mathrm{P}=\mathrm{Ao}+\mathrm{A} 1 \mathrm{C}+\mathrm{A} 2 \mathrm{~N}$, где: $\mathrm{P}$ - Productivity (raw weight, $\mathrm{g} / \mathrm{m}^{2}$ ), $\mathrm{C}$ - coverage $(\%), \mathrm{N}-$ number of shoot (per $\mathrm{m}^{2}$ ). Biological stock (BS) of A. uva-ursi in Kirov Region reaches 285,5 t. Distribution of BS among vegetative subzones and administrative regions is uneven: $51 \%$ of $\mathrm{BS}(144,7 \mathrm{t})$ is concentrated in middle taiga subzone. Exploitation stock (ES) in the Region reaches 109,1 t. Volume of possible annual collection - 7,9 t, which is enough for local needs. In lichen pine forests with areas of $A$. uva-ursi in Kirov Region when $75 \%$ of peripheral shoots are cut, it does not recover within 5-years period between collections.

Keywords: Arctostaphylos uva-ursi; phytocoenotic confinement; phytocoenotic optimum; coenorange; productivity; coverage; biological stock; exploitation stock; volume of possible annual collection; exploitation press; Kirov Region.

УДК 581.5

Статья поступила в редакцию 30.12.2017

\section{ТАКСОНОМИЧЕСКАЯ И БИОМОРФОЛОГИЧЕСКАЯ СТРУКТУРА ФЛОРЫ СОСУДИСТЫХ РАСТЕНИЙ ГОРЫ КУЗНЕЦОВА (САМАРСКАЯ ОБЛАСТЬ, ВОЛЖСКИЙ РАЙОН)}

(C) 2018

Макарова Юлия Владимировна, кандидат биологических наук, старший преподаватель кафедры экологии, ботаники и охраны природы Самарский национальный исследовательский университет имени академика С.П. Королёва (2. Самара, Российская Федерация)

Головлёв Алексей Алексеевич, доктор географических наук, профессор кафедры мировой экономики Самарский государственный экономический университет (2. Самара, Российская Федерация)

Прохорова Наталья Владимировна, доктор биологических наук, профессор кафедры экологии, ботаники и охраны природы Самарский национальный исследовательский университет имени академика С.П. Королёва (2. Самара, Российская Федераџия)

Аннотация. На горе Кузнецова установлено произрастание 267 видов сосудистых растений из 190 родов, 63 семейств, 26 порядков, 4 классов (Equisetopsida, Polypodiopsida, Pinopsida, Angiospermae) и 3 отделов (Еquisetophyta, Polypodiophyta, Spermatophyta). Абсолютное большинство видов относится к отделу Spermatophyta (258 видов, 96,7\%), классу Angiospermae (257 видов, 96,3\%), группе Dicotyledones (228 видов, 85,4\%). Сосудистые споровые растения представлены 9 видами, принадлежащими к 6 родам (Equisetum, Matteuccia, Athyrium, Cystopteris, Dryopteris, Pteridium), 5 семействам (Equisetaceae, Onocleaceae, Woodsiaceae, Dryopteridaceae, Dennstaedtiaceae), 2 классам (Equisetopsida, Polypodiopsida) и 2 отделам (Equisetophyta, Polypodiophyta). Ведущими по числу видов являются семейства Compositae (44 вида, 16,5\%), Leguminosae (22 вида, $8,2 \%$ ) и Rosaceae (18 видов, 6,7\%). Ведущими по числу родов - семейства Compositae (29 родов, 15,3\%), Rosaceae (14 родов, 7,4\%) и Labiatae (13 родов, 6,8\%). Наибольшее число видов сосредоточено в родах Trifolium (7 видов), Viola, Campanula, Galium и Carex (по 4 вида). По системе климаморф К. Раункиера во флоре доминируют гемикриптофиты (148 видов, 55,4\%). По системе биоморф И.Г. Серебрякова и Т.И. Серебряковой - поликарпические короткокорневищные, длиннокорневищные и стержнекорневые травы (47,0\%). Вегетативно неподвижными и малоподвижными являются 76,8\% видов.

Ключевые слова: флора; сосудистые растения; таксономический анализ; биоморфологический анализ; жизненная форма растения; биоморфа; климаморфа; фанерофит; хамефит; гемикриптофит; криптофит; терофит; 